\title{
An Assessment of Analysis on the Penetration of Malaysian Contractors into India
}

\author{
Nur Aishah Mohd Hamdan, Hamimah Adnan \\ Department of Quantity Surveying \\ Faculty of Architecture, Planning and Surveying \\ Universiti Teknologi MARA,Shah Alam, Selangor \\ MALAYSIA \\ E-mail: hamimah_uitm@yahoo.com.my
}

\begin{abstract}
This paper will give insight to India as a developing country and an emerging super-power in the world's economy. It will explain the factors that contribute to the development of India and the changes India has gone through to achieve the success. Following a thorough literature review, questionnaire surveys were sent out to G7 contractors registered under CIDB Malaysia to understand the situation of contractors in their venture into the Indian construction market. It was found that the successful contractors viewed profit margin as the most important factor when tendering compared to building reputation in the Indian market. The contractors need to make groundwork or research, build/increase tolerance and skills in negotiation. An offer of attractive financial package and comprehensive services and good Indian partnership with local representatives to build better relationship and accumulate better market information are several main factors to succeed in the Indian construction market. The findings of this research provide useful information for any contractors to their intention in penetrate the Indian construction market.
\end{abstract}

Keywords: Penetration, Malaysian Contractors, India

\section{Introduction}

The Indian construction industry growth was quite volatile especially in the early years since the liberalisation of its economy. The growth has escalated to a more comfortable momentum since 1998 due to the intensification of construction investments by the government. Institutional and administrational reform to make construction investments more feasible had successfully lured foreign investors into participating in the development of India's construction. According to the World Construction Outlook 2003-05 by Davis Langdon \& Everest, London, India ranks $12^{\text {th }}$ in the Global construction market and this amounted to 4 trillion dollars (Davis Langdon \& Seah International, 2003). The same study forecasted an average growth rate of 5\% per annum in construction investment world over by 2012 and India is growing at considerably higher rates of $7.9 \%$ per annum, making it the third largest behind China and the US in economy.

Indian construction, which was previously lagging now provide ample opportunities in sectors such as road and highways, power, telecom, ports, airports, real estate as well as urban infrastructure. In the course of time, the industry will evolve and settle into order. At present time however, the standard of construction technology in India is backward Malaysia by 10 to 15 years in comparison to Malaysia. The biggest construction projects implemented by the Indian Government are infrastructure projects mainly road constructions. However, the government also needs to close the widening gap between demand and supply for other infrastructure developments such as power, telecom, ports, airports and recently the increased demand for urban infrastructure to complement the interest of the public for real estate. Economic reforms are aimed to accelerate the country's growth to be on par with other developed nations. Its large population creates a massive market for economic. The biggest middle-income population with impressive education, India was the preferred choice for outsourcing of labours and manufacturing activities.

In realising its full potential, India has developed extensive infrastructure development programmes to accelerate the involvement of foreign investors in the country. India is also determined to provide acceptable living condition for its people. Lack of experience in massive infrastructure construction projects had opened up windows for global construction players to penetrate the market. Major policy changes were implemented to accommodate the construction players in effectively executing the projects. Increased incentives are given to BOT projects to reduce capital spending by the Indian Government. It is also a means to secure long term investments of foreign contractors in the Indian market. This is most beneficial for Malaysian contractors who have had the experience of executing similar jobs locally. 
To date, Malaysian contractors have completed 47 projects valued at RM7.397 billion (US\$ 28 billion) in India. The value itself reflects the high involvement of Malaysian contractors in the country's construction sector. Research had indicated that the sector that attracted the most involvement of Malaysian companies was in the road and highways sector with a turnover value of almost $81 \%$ from the overall value of secured contracts. However, the efforts were not free from various obstacles and difficulties. Among the main difficulties encountered were bureaucracy and delays from the client, the contrast in culture and working environment and the unexpected costs incurred due to unfavourable taxes and corruption among Government officials.

Most Malaysian contractors were able to sustain through the difficulties to maintain their operation in the market with exception to a few. Self financed visits were the most common initial research done to gather first hand information on the market environment. Independent representative offices are a necessity for long term operations to reap full benefits of the market and to ensure efficient operations.

The hurdles faced by Malaysian contractors were addressed using salient strategies to achieve favourable success from the venture. The strategies were formulated as a response to anticipate obstacles and towards realising the company's vision. Low initial profit for longer market operation and diversification of company's activities had shown considerable success for the companies.

The most important thing as perceived by the Malaysian contractors is to have strong financial capacity as the road to success in India is barricaded by unexpected costs. Well diverse experience in several sectors has provided high level of endurance for the companies. Trust, compliance to client's requirement and quality in construction serve as the route to gain recognition in the market. Once trust on the capabilities is established, further expansion in the market is a smooth sailing journey.

India's embarkation on an ambitious infrastructure development programme will continue to provide huge opportunities for Malaysian contractors. Most ventures had proved to be profitable for Malaysian contractors. The determination to push through difficulties and conducting thorough studies separate the success and failures of the market venture.

\section{Opportunities in theindia construction sector}

Construction activities are an integral part of the development of a country. The integration of other industries through forward and backward linkages makes construction an important part in ensuring continuous growth. India is committed to provide the best infrastructure facilities for its people. The vision is to provide world class infrastructure in India. Therefore, to realise the challenge, the capacity of construction has been increased through massive investments by the government and private sectors creating substantial construction opportunities in the Indian construction market.

\subsection{Real Estate Sector}

The nationwide housing shortage in India is estimated at 20 million residential units and continues to increase. Rapid population growth and the growth of India's middle class, is creating demand for housing. Indian macroeconomic fundamentals are strong and the changing economic profile and demographics cater well for all segments of the industry. With income yields at $10 \%-12 \%$, the Indian real estate sector is one of the most attractive sectors for investment. Commercial space requirements across a range of industries have soared. The fastest-growing sectors, IT and IT-enabled services (ITES), is expected to require 50 million to 70 million square feet of space over the next two to three years (CIDB, 2005). The government has begun to develop a mortgage market. Financing is becoming available to more first-time buyers and buyers of second or vacation homes.

\subsection{Roads and highways}

India has more than 3 million $\mathrm{km}$. of road network, making it one of the largest in the world. However, the quality of the roads is inappropriate and cannot meet the needs of efficient and fast moving transportation. National Highways are the prime arterial route span about $52,010 \mathrm{~km}$ throughout the country and cater to about $40 \%$ of the total road transport demand. The National Highway Authority of India (NHAI) was constituted under the National Highway Authority of India Act, 1988 and was made operational in February 1995. Initially it was entrusted with the task of implementing five externally aided National Highway improvement projects. Subsequently, it was asked to implement several other projects including some BOT projects on National Highways.

NHAI has been mandated to implement National Highway Development Program (NHDP) which constitutes 4/6 laning of Golden Quadrilateral Connecting Delhi-Mumbai-Chennai-Calcutta-Delhi and North-South and East-West Corridors connecting Kashmir to Kanyakumari and Silchar to Saurashtra respectively and Salem to Cochin.

To encourage private sector participation, a Model Concession Agreement for major projects costing more than US \$ 222.22 million has been introduced under BOT Scheme. Another Model Concession Agreement for projects less than US \$ 222.22 million has also been introduced by the Government. To date 20 projects involving an investment of around US \$222.22 million have already been taken under BOT scheme (CIDB, 2005). 
With a major shift from the railways to roads, the potential to develop national highway is immense, considering the fact that the national highways represent less than $2 \%$ of the overall road network, although traffic density is $40 \%$ (NST, $28^{\text {th }}$ November 2003).

\subsection{Airport}

Airways form a very important role in India's economy. It plays a very important role in the overall transportation network plus in India's foreign trade. It also has a big impact on the tourism industry as majority of the foreign tourists arrive through air transport.

In India, there are around 450 airports, including those managed by the defence services, government local bodies and private parties. The management of the civil airports is under Airports Authority of India (AAI). AAI manages 120 airports including 5 international airports (Mumbai, Delhi, Chennai, Kolkata and Bangalore), 87 domestic airports and 28 civil enclaves.

According to the 11th Quarterly Survey of Projects Investments (30 June 2003) conducted by ProjectsToday, the industry had 63 projects worth US $\$ 4435.77$ million in various stages of planning and implementation. These include new airports and renovation and modernization of the existing ones (CIDB, 2005).

The bulk of the projects investment is in the new international airports proposed at Maharashtra, Karnataka, Andhra Pradesh, Goa and Uttar Pradesh. The state and the sentral government form the major part in terms of projects investments.

\subsection{Ports}

India with a coastline of $6,000 \mathrm{~km}$ has 12 major and 139 minor/ intermediate ports. The major ports are situated at Mumbai, Navi Mumbai, Chennai, Kolkata, Paradip, Mangalore, Kochi, Ennore, Kandla, Visakhapatnam, Tuticorin and Mormugao. All ports together handle $90 \%$ of India's foreign trade, in terms of tonnage. Major ports account for nearly $75 \%$.

Minor ports in India are under-utilized as the major ports handle most of the traffic. This overstretches their capacity resulting in high turnaround time and pre-berthing delays.

According to World Bank estimates, the delay in container handling costs India $\$ 70$ million per annum. Long turnaround time also adds up to the cost of the products. In 2000, the major ports handled 272 million tonnes as against the capacity of 258 million tonnes implying a capacity utilisation of $105 \%$ (CIDB, 2005).

According to the 11th Quarterly Survey of Projects Investments (30 June 2003) conducted by Projects Today, the industry had 45 projects worth US\$ 7,528.44 million in various stages of planning and implementation. Out of the 45 projects, as many as 39 projects constituting $91 \%$ of the investment were in initial stages. Only three projects with an investment of US\$ 715.33 million were under execution. Thus the project implementation ratio was very low (CIDB, 2005).

The majority of investments in ports were by the private sector (around 63\%). The state governments accounted for $31 \%$ and the Central government's share was a mere $6 \%$. In the private sector, $18 \%$ of the total investments have been envisaged by foreign companies while the domestic companies share stood at $44 \%$.

Around $60 \%$ of the investment in the port projects was concentrated in the western coast. The investment is also skewed in the eastern coast with Andhra Pradesh and Tamil Nadu cornering $64 \%$ of the investment in the region.

\subsection{Urban Infrastructure}

Urban infrastructure refers to the framework of facilities to promote and sustain human settlements. In India, the term refers to water supply, sanitation, solid waste management and street lighting (Venkatachalam in Rajesh, 1999).

Rapid urbanisation has led to pollutions of river waters and falling groundwater levels. The annual cost of environmental degradation is around $4.5 \%$ of the GDP. Only $58 \%$ of the urban population have access to potable water (Ramakrishna, 2004).

Therefore, technological interventions from experienced parties are badly needed to provide a well developed water supply system for India. Currently, investments in BOOT projects estimated at US\$221 million are in place. In the next two to three years, the government is expected to invest approximately US\$9.5 million for the modernisation water supply and urban sanitation. Recently, the opportunities include the encouragement private investment in Mass Rapid Transit System (LRTS). Cities planning to introduce MRTS system include New Delhi, Bangalore and Hyderabad (India Business Opportunities, 2001).

\subsection{Power}

The growth of the economy developed a surging need for increased power supply in all parts of the country. In order to sustain to GDP growth of $6 \%$ per annum, the demand for power was expected too grow at $9 \%$ per annum. 
The investments for power supply have always been under the responsibility of the public sector. The National Thermal Power Corporation is India's largest power generating company and is under the jurisdiction of the central government. Currently, the investments in power supply have attracted the interests of private investors. Despite increased supply, the demand still cannot be met.

India continuously faced power shortages. In 1999, the energy shortage was about $8 \%$ and at peak times was about $17 \%$. Also, per capita energy consumption in India is among the lowest in the world. China and India was reported to need almost $40 \%$ of the additional requirement on electricity in the world (Venkatachalam in Rajesh, 1999). Over the last decade, while electricity consumption has been increasing at an average annual rate of 8-9\% per year, supply has increased by only $7.5 \%$.

\subsection{Telecom}

The Indian telecom network has been ranked among the top 15 networks in the world with over 14 million lines. Due to its wide geographical area, it needs a wide telecom network. India's Infrastructure: Investment Opportunities, in 1997 placed India's telecom network as the twelfth largest in the world and third largest in the developing world (Rajesh, 1999).

Until recently, the telecom sector was monopolised by local companies covering only in operation. The telecom sector today has wide range of services like cellular radio paging, voicemail and videotext service. Value added services are mostly provided by private operators. The technological advances have provided endless possibilities of services in this sector.

The demand for basic telephone services is expected to be about 64 million lines in 2006 . To meet the demand, it was expected an additional of 52 million lines will have to be added over the next ten years.

\section{Aim of the research}

The aim of the research is to identify the construction strengths, opportunities, weaknesses and threats that are exposed to Malaysian contractors in India.

\section{Research methodology and analysis of findings}

Questionnaire surveys were adopted and carried out on selected Grade G7 Malaysian contractors registered under the Malaysian Construction Industry Development Board Malaysia who had working experience in India. The objective of the questionnaire survey is to assess the general environment of operation for Malaysian contractors in the venture into the Indian construction market. The method used for this analysis is statistical data formulation and the data presented is in terms of percentages $(\%)$.

The Questionnaire was divided into two (2) sections.

Part A

Question 1- General Information

1)Does your company still operate in India?

Out of fourteen (14) contractors who had completed the questionnaire, only two have stopped their operation in India. This indicates a rate of $86 \%$ 'successful' as compared to $14 \%$ of 'unsuccessful' Malaysian in penetrating and maintaining their venture in the Indian construction market.

2) How long has your company been operating in India?

Fifty percent $(50 \%)$ of the successful contractors' operational period ranges for less than five years. Forty two percent $(42 \%)$ successful contractors' operational period ranges less than 10 years. Eight percent (8\%) successful contractors' operational period ranges more than ten years. From the response, Malaysian contractors who ventured into the Indian construction market have had reasonable time to experience and understand the market environment.

3) How much do you know of the contracting opportunities that are opened to foreign companies in India?

Seventy five percent $(75 \%)$ of the successful respondents have much knowledge of the opportunities that were available in India, seventeen percent (17\%) claimed they have much knowledge on the opportunities available in the market. Only eight percent $(8 \%)$ of the successful contractors have little knowledge of the opportunities. Hundred percent $(100 \%)$ of the unsuccessful contractors attested to having much knowledge in the Indian construction market. This proves that knowledge of opportunities does not always aid the contractors to be successful in the foreign market.

4) From which source did you learn of the opportunities mentioned above?

This question was a continuation of the previous question regarding the knowledge on opportunities available in the Indian construction market. The source that provided the most information on the opportunities as responded by the successful contractors was CIDB (Construction Industry Development Board) of Malaysia with twenty two percent 
(22\%), followed by private agencies or market research groups and also international construction journals and consultants of previous jobs with fifteen percent (15\%) and twelve percent (12\%) respectively.

Despite the efforts of Government agencies such as MITI (Ministry of Trade and Industry of Malaysia) and MATRADE (Malaysian External Trade Development Corporation) as well as the Malaysian Embassy in India in organising trade missions and business seminars, the three agencies only received seven percent (7\%) of the responses. The stock and merchant banks and Indian Embassy provided the least information for the successful contactors, both as only five percent $(5 \%)$ of the responses. Sixty seven percent $(67 \%)$ of the unsuccessful contractors felt that clients of previous jobs gave them the most information on the opportunities followed by sixty three percent $(63 \%)$ who gathered information from consultants of the same category.

Part B - Company's Operation in India

5) What is/are the types of work that your company will execute / are executing / have executed in India?

Some successful contractors have been involved in various types of construction works in India. However, many of them only focused on only one type of work. Thirty three percent (33\%) of the successful respondents are executing / have executed road building projects. Seventeen percent (17\%) of the successful respondents are / were in the public utility business mainly in the water and water treatment services. Eleven percent (11\%) of the construction on airports projects and real estate development was secured. Others include power, oil and gas and buildings sector as well as metro rail project and structural steel works (design and erection). Each of the above carries a marginal six percent (6\%) response from the respondents.

Meanwhile, fifty percent (50\%) the unsuccessful contractors were involved in the oil and gas sector and the other fifty percent $(50 \%)$ were in the road building sector. None of the respondents are / were involved in any ports projects in India. Major involvement of Malaysian contractors in road building sector supports the literature review that states the road and highways projects as having the highest value of work done by Malaysian contractors at eighty percent $(81 \%)$ from the total value of projects executed in India (Unpublished report from CIDB, 2006).

6) What type of tendering system did you enter for the projects mentioned above?

Thirty-nine percent (39\%) of the successful contractors responded that the open tender method was selected as the most popular tendering system entered in India. Competitive bidding followed this with twenty-eight (28\%) respondents. The least preferred tendering system by the successful contractors was through negotiation and government to government agreement with seventeen percent (17\%). Hundred percent (100\%) of the unsuccessful respondents were involved in competitive bidding to secure projects in India.

It was noted that the contractors who managed to secure projects under the Government to Government system were involved with the consortium formed under the Malaysian Construction Industry Development Board Inventures.

7) What type of procurement system did you used for the projects mentioned above?

Despite various considerations given to BFOT (Build, Operate, Finance and Transfer) contracts, seventy one percent (71\%) of successful Malaysian contractors were keen to be involved in Lump Sum using BQ (Bills of Quantities) or Drawing and Specification contracts. Only twenty-nine percent $(29 \%)$ of the respondents were involved in BFOT projects. For the unsuccessful contractors, hundred percent (100\%) of the respondents were involved in the Lump Sum contracts.

The reason behind the responses is that BFOT contracts involve higher financial capabilities and longer time to recoup profits. Lump Sum contracts usually provide clear cut basis for pricing and claims and require only several years of involvement. None of the respondents were involved in Management contracting procurement system.

8) What is the average contract period of the types of works mentioned above?

Eighty three percent (83\%) of the successful respondents were involved with projects with an average contract period of below five years. Seventeen percent (17\%) respondents were involved in projects with an average contract period of five to ten years. Hundred percent $(100 \%)$ of the unsuccessful contractors were also involved with projects with an average contract period of five to ten years.

None of the respondents were involved with projects with less than one year or more than ten years of average contract period. Assumptions made that the value of contracts involved by the contractors were considerably quite large due to the average contract period ranging from two (2) to ten (10) years. Shorter contract period also provided opportunities for Malaysian contractors to be involved in other projects as well.

9) How did you first make your foothold in India?

Forty percent $(40 \%)$ of the successful respondents used self promotion and joint ventures with Indian partners in making their foothold in the Indian construction market respectively. Fourteen percent (14\%) of the successful 
respondents entered the market through joint ventures with other Malaysian companies. Seven percent (7\%) made their foothold under the alliance with the Malaysian government.

Fifty percent $(50 \%)$ of the unsuccessful contractors first made their foothold in the market through self promotion and another fifty percent $(50 \%)$ through joint venture with Indian partners.

The choice of entering the Indian construction market was previously through a Joint Venture with an Indian partner, which was the main selection of Malaysian contractors. The trend is assumed to change with the increasing number of self promoted contractors to India. Currently, this is the most popular choice of entry due to lesser dependency on the Indian counterparts with an increasing knowledge on the market operation provided by the pioneers who have succeeded there.

10) Do you have any representative office(s) in India?

Sixty seven percent $(67 \%)$ of the successful contractors have at least one representative office in India. Only thirty three percent $(33 \%)$ chose not to have any representative office there. Hundred percent $(100 \%)$ of the unsuccessful contractors also have representative offices in India.

Physical presence through representative office(s) was a necessity for contractors who entered the Indian market through self promotion or by partnering with Malaysian counterparts in order for them to be able to bid for projects. In addition, representative office(s) allowed the contractors (regardless of method of market entry) to closely monitor and have first hand experience of operating in the Indian environment.

11) How long have the office(s) mentioned above been in operation?

Operational period of representative office(s) can make significance difference in the venture of Malaysian contractors into the Indian construction market. Seventy percent (75\%) of the successful contractors (who have representative office(s) in India) decided to have their representative office(s) after securing the first contract compared to only twenty five percent (25\%) who had had their office(s) since before getting any contract.

While fifty percent (50\%) of the unsuccessful contractors chose to have the representative office(s) before getting any contract, another fifty percent (50\%) decided to have at least one after securing their first contract.

Although having representative office(s) before getting any project involves high costs to maintain, it had given the contractors early market presence and invaluable experience before actually getting involved in the market. However, a safer route would be to secure a contract prior to the opening of any representative office(s), which explained the answers gained from the respondents.

12) When tendering for projects in India, how would you rank or have ranked the following factors? $(1=$ the most important......4=the least important)

Fifty eight percent $(58 \%)$ of the successful contractors confirmed that profit margin outweighed other factors as the most important factor for the successful contractors when tendering for projects in India. This is followed by the need for quality and speed, good relationship with clients and the importance of building a reputation in the Indian market with thirty three (33\%),twenty five (25\%) of responses respectively.

The factors which were viewed as important by the successful contractors were quality and speed (50\%), good relationship (25\%), profit margin (17\%) and building reputation in the market (17\%).

Meanwhile, only twenty five percent (25\%) of the said contractors thought that building reputation in the market was less important compared to seventeen percent (17\%) who selected all other factors. Thirty three percent (33\%) chose having good relationship with the client and building a reputation in the Indian market as essential another eight percent $(8 \%)$ replied that profit margin was the least important factor when tendering contracts in India.

Fifty percent $(50 \%)$ of the unsuccessful contractors confirmed that building reputation in the market was considered as the most important factor. All confirmed that creating a good relationship with the client was important to the contractors when tendering in the Indian market.

The most significant difference was seen is the selection of most important factors by the successful and unsuccessful contractors. The successful contractors viewed profit margin as the most important factor when tendering compared to building reputation in the market as selected by the unsuccessful contractors.

13) What is the preparatory and early initiatives did your company undertaken before getting the contract?

Preparatory work for ventures is vital in order to ensure the success of the ventures into the Indian construction market. Thirty-two percent (32\%) of the successful contractors had initiated self financed visits to India to really uncover the potentials and threats that forced them in the market. The second highest effort with twenty one percent $(21 \%)$ was through acquisition and exhaustive study of reference materials. Other preparatory work done by the successful contractors included consultation with agencies (18\%), participation in trade missions and exhibitions (15\%), 
subscription to bodies such as CIDB and/or MITI for notices of tendering opportunities (9\%), information search using internet (3\%) and referring to others' experiences $(3 \%)$.

Sixty seven percent $(67 \%)$ of the unsuccessful contractors prepared themselves by conducting self financed visits to India and thirty three (33\%) decided to administer acquisition and exhaustive study of reference materials.

The similarities between the successful and unsuccessful contractors were the selection of self financed visits as well as acquisition and exhaustive study of reference materials as the second essential step of the preparatory work. Self financed visits gave the companies the necessary interaction with the Indian people who operated in the market and the ability to relate to the companies' visions. Although very costly, the importance of the visits was substantial for the success of the ventures. The abundance of reference materials made preparatory work relatively easy.

14) What are the factor(s) that might contribute to your success (defined as having won or managed to get involved in a contract)? (Strongly agree ........Strongly disagree)

Fifty percent $(50 \%)$ of the successful contractors strongly agreed to early and thorough groundwork or research, increase in tolerance and skills in negotiation, offer of attractive financial package and comprehensive services and good local partnership with local representatives to build a better relationship and accumulate better market information as the main factors to succeed in the Indian construction market. Fifty percent $(50 \%)$ of the respondents agreed on low price over long term strategy and good relationship and contact with the Indian construction players in obtaining success in the construction market.

However, another forty two (42\%) disagreed with the low price over long term strategy factor. Meanwhile, thirty-three $(33 \%)$ of the successful respondents were undecided whether building culturally sensitive and effective marketing and promotion strategies and using less formal interaction patterns contributed to their success in the market.

Eight percent $(8 \%)$ of the contractors strongly disagreed that using less formal interaction patterns and strategic alignment with the Malaysian Government helped to made them successful in India.

Fifty percent $(50 \%)$ of the unsuccessful contractors strongly agreed that tolerance and skills in negotiation and good relationship and contact with Indian customers, partners, employees, authorities and businessmen contributed the most in order to succeed in India. Hundred percent (100\%) of the said contractors agreed on conducting early and thorough groundwork research as well as having good local partners with local representative to build better relationship and effective marketing together with strategic alignment with Malaysian Government agencies. They disagreed with low price over long term strategy and using less formal interaction patterns to create a comfortable relationship with the Indians towards the contribution of their success in the market. Offers of attractive financial packages and comprehensive services were the only factor that the unsuccessful contractors strongly disagreed for helping them to succeed.

From the findings, it can be concluded that the most important factor to succeed in the Indian construction market from the views of both the successful and unsuccessful contractors was having better tolerance and increased skills in negotiation. .

15) Please indicate the extent of your agreement on the following difficulties of operation in India. (Strongly agree .........Strongly disagree)

A majority of both the successful and unsuccessful contractors (50\%) strongly agreed to Indian bureaucracy as being the greatest setback with regards to operation in India. Three difficult factors which were contradictive in response when received equal percentages of agreement and disagreement form the successful contractors,: 1- Inadequate and inefficient infrastructure and facilities (33\%), 2 - Different cultures and languages pose great problems with lower level management (33\%), and, 3 - Lack of adequate information and difficulty to access and uncover potential partners, their capabilities and commitment (32\%). Twenty-five percent $(25 \%)$ of the successful contractors were undecided on the out-of-date and inefficient working techniques, management styles and values of local partners.

While half $(50 \%)$ of the unsuccessful contractors were undecided regarding the inadequacy and loose interpretations of the laws and regulations, all of them (100\%) decided to disagree with the differences in culture and language as posing difficulties to operate in the market. Twenty-five percent (25\%) of the unsuccessful contractors strongly disagreed with the out-of-date and inefficient working techniques factors. No response was obtained towards the factor of unreliable local partner as being part of the setbacks when operating in India.

A strong agreement from both the successful and unsuccessful contractors on Indian bureaucracy confirmed the findings of the research done by Boston Consulting Group that listed this as the biggest drawback of difficulties of doing business in India (Planning Commission, Government of India, 2002). The wide range of responses towards other difficulties of operation in India might be due to different types of work involved by the Malaysian contractors, which exposed them to different sets of working groups and working environment.

Part C - Company's Perception of India 
16) In your opinion, what are factors attract foreign contractors into India?

Sixty-seven percent $(67 \%)$ of the successful contractors and fifty percent $(50 \%)$ of the unsuccessful contractors perceived India's massive infrastructure projects as the most important factor that attract foreign contractors into India. Fifty eight percent $(58 \%)$ of the successful contractors and all of the unsuccessful contractors cited that rapid development in India was an important factor for securing contract.

All (100\%) of the unsuccessful contractors selected the availability of many English speaking professionals as an important part in attracting foreign contractors into India. Thirty percent $(30 \%)$ of successful contractors considered the factor as less important, and decided that a large pool of cheap labour was an important factor. Attractive FDI (Foreign Direct Investment) policies were viewed as being less important, accounting for forty percent (40\%) and fifty percent $(50 \%)$ of the responses from the successful and unsuccessful contractors respectively.

The main attraction of India to the international contractors ranges from the abundance of natural resources of India having a large pool of cheap as well as availability of English speaking professionals (MATRADE, 2005) to the liberalisation of the Indian economic which includes the rapid development of India by incorporating attractive FDI policies and massive infrastructure projects (Anandarajah \& Granados in Tan et al, 1996).

17) How do the following situations influence the growth of the construction industry in India.

Only twenty seven percent (27\%) of the successful contractors rated the change of ruling government as well as economic stability as the most important effects towards the prospects of India of becoming an emerging market in the field of construction. A significant response of seventy-three percent (73\%) viewed economic instability as an important part in the matter. Thirty six percent (36\%) of the contractors selected the change of ruling government as being less important and political crisis with neighbouring country as the least important aspect to consider.

Fifty percent $(50 \%)$ of the unsuccessful contractors chose economic unstability influence as being the most important. All the responses felt that change of investment portfolio by the Indian Government was of great influence. The contractors also viewed political crisis with neighbouring countries having little or least effect.

The most important factors that could affect the prospect of India as an emerging market for construction as selected by the successful (change of ruling government) and unsuccessful contractors (economic instability) are actually interrelated with one another. A strong government which supports the long term investment in the construction sector is seen as highly important to provide stability of growth for the country especially in competing with its rivals. Although the political crisis between the neighbouring countries namely China and Pakistan will remain to continuously pose problems to India, the impact is minimal.

\section{Conclusion}

The research has provided extensive views into the operation of Malaysian contactors in the Indian construction market. However, the findings have not been able to reflect the true level of success of Malaysian companies as compared to other foreign players in the Indian market. Therefore, it is recommended that further research be carried out on the comparison of market turnover between all foreign contractors that have managed to penetrate the Indian construction market.

The successful contractors viewed profit margin as the most important factor when tendering compared to building reputation in the Indian market. This should be done through the acquisition and exhaustive study of reference materials. The contractors need to conduct thorough groundwork or research and increase tolerance and skills in negotiation. An offer of attractive financial package and comprehensive services and good local partner with local representative to build better relationship and accumulate better market information as the main factors is important to succeed in the Indian construction market . Contractors also agree on low price over long term strategy and good relationship and contact with the Indian construction players.

The wide range of responses towards other difficulties of operation in India might be due to different types of work involved by the Malaysian contractors, which exposed them to different sets of working groups and environment. The findings will provide useful information for any contractors to pursue their intention in penetrating into the Indian construction market.

\section{References}

Anandarajah \& Granados in Tan et al. (1996). "Business Opportunities in India", Nanyang Technological University, Singapore, Prentice Hall

Construction Industry Development Board Malaysia. (2006). Unpublished Report from CIDB, "Projects Undertaken By Malaysian Contractors"

Davis Langdon \& Seah International. (2003). World Construction Review Outlook 2003/04 (2003). Retrieved February 15,2006 
MATRADE (2005). Retrieved June 20, 2005, from Malaysia External Trade Development Council

Mitton, Roger (2000). Cover Story INDIA, ASIAWEEK, 26:13, 30-49

Web site : http://www.davislangdon.com.au/publications/worldreview0304.pdf

MATRADE (2005). Retrieved June 20, 2005, from Malaysia External Trade Development Council

Web site: http://www.matrade.gov.my

Planning Commission, Government of India. (2002). "Report of the Steering Group on Foreign Direct Investment", New Delhi, Shipra Publications

Ramakrishna. (2004). A “Trade \& Investment Opportunities" in Infrastructure Sector in Shah, Rajesh V Ed (1999) Doing Business with India, Kogan Page, London MATRADE/CII Seminar On "Doing Business With India"

Tan, Meng Teck (Ed). (1996). "Business Opportunities in India”, Nanyang Technological University, Singapore, Prentice Hall 